\title{
Kepatuhan bank syariah di Indonesia dalam menjalankan kegiatan usahanya terhadap ketentuan syariah compliance
}

\section{Mohammad Ghufron Az.}

Mohammad Ghufron Az; Fakultas Hukum, Universitas Merdeka Malang; Jl. Terusan Raya Dieng No. 62-62, Malang, Jawa Timur 65146, Indonesia.

ARTICLEINFO

Article history:

Received 2020-06-09

Received in revised form

2020-07-02

Accepted 2020-08-01

Kata kunci:

Bank Syariah; Syariah Compliance;

Prinsip Syariah; Perlindungan Hukum.

Keywords:

Sharia Bank; Sharia Compliance; Sharia Principle; Legal Protection.

DOI: $h$ ttps://doi.org/10.26905/

idjch. v11i2. 4396.

How to cite item:

Ghufron Az, M. (2020).

Kepatuhan Bank Syariah di Indonesia dalam Menjalankan Kegiatan Usahanya Terhadap Ketentuan Syariah Compliance. Jurnal Cakrawala Hukum, 11(2), 187-193. doi:10.26905/ idjch.v11i2. 4396

Corresponding Author:

* Mohammad Ghufron Az.

E-mail address: mohammad_ghufron@yahoo.com

\section{Abstrak}

Fokus penelitian ini adalah tentang kepatuhan Bank Syariah di Indonesia dalam menjalankan kegiatan usahanya terhadap ketentuan syariah compliance. Tujuan utama dari penelitian ini adalah untuk menganalisis kepatuhan Bank Syariah di Indonesia dalam menjalankan kegiatan usahanya terhadap ketentuan syariah compliance sebagaimana ditentukan dalam undang-undangtentang Perbankan Syariah. Pendekatan yuridis normative dan pendekatan yuridis empiric dipergunakan dalam penelitian ini. Hasil penelitian menunjukkan bahwa secara yuridis formal telah diatur dalam undang-undang tentang Perbankan Syariah bahwa bank syariah dalam operasionalnya harus tetap menjalankan prinsip syariah secara menyeluruh (kaffah) dan konsisten (Istiqamah). Prinsip kehati-hatian Bank Syariah harus melakukan penyimpangan dari prinsip syariah yang seharusnya dipatuhi. Seperti dalam Perjanjian Mudharabah dan Musyarakah, menurut prinsip syariah bank syariah tidak diperbolehkan mensyaratkan adanya jaminan, karena dengan adanya syarat jaminan maka perjanjian Mudharabah dan Musyarakah menjadi batal demi hukum. Apabila tidak ada jaminan maka perlindungan tehadap bank sangat lemah karena akan banyak terjadi pembiayaan yang macet yang akhirnya merugikan masyarakat penyimpan dana di bank syariah. Jaminan dalam perjanjian Mudharabah dan Musyarakah untuk mencegah terjadinya pembiayaan yang macet dan dalam rangka melindungi masyarakat penyimpan dana.

\section{Abstract}

The focus of this research is on the compliance of Islamic banks in Indonesia in carrying out their business activities to the provisions of sharia compliance. The main objective of this research is to analyze the compliance of Islamic banks in Indonesia in carrying out their business activities against the provisions of sharia compliance as stipulated in the law on Islamic banking. The normative juridical approach and the empirical juridical approach were used in this study. The result of the research shows that in formal juridical terms it has been regulated in the law 


\section{Jurnal Cakrawala Hukum, Volume 11 No. 2 Agustus 2020 \\ ISSN PRINT 2356-4962 ISSN ONLINE 2598-6538}

concerning Islamic Banking that in its operations, Islamic banks must continue to carry out Islamic principles as a whole (kaffah) and consistently (Istiqamah). The principle of prudence Sharia banks must deviate from the sharia principles that should be adhered to. As in the Mudharabah and Musyarakah Agreements, according to sharia principles, Islamic banks are not allowed to require collateral, because with the guarantee conditions the Mudharabah and Musyarakah agreements become null and void by law. If there is no guarantee, then the protection for the bank is very weak because there will be a lot of bad financing that will eventually harm the people who deposit funds in Islamic banks. Guarantee in the Mudharabah and Musyarakah agreements to prevent non-performing financing and in order to protect the people who deposit funds.

\section{Latar Belakang}

Bank Islam di Indonesia mulai berdiri dan beroperasi pada tahun 1992, yaitu sejak diundangkannya Undang-Undang No. 7 Tahun 1992 Tentang Perbankan. Pada saat itu bank Islam dikenal dengan istilah "bank berdasarkan prinsip bagi hasil". Diijinkannya Bank Islam beroperasi di Indonesia adalah dalam rangka memfasilitasi masyarakat Islam yang tidak mau berhubungan dengan bank konvensional karena bank konvensional menerapkan sistim bunga. Menurut hukum Islam sistim bunga masuk katagori riba yang haram hukumnya. Di sisi yang lain operasional bank Islam di Indonesia adalah dalam rangka memberikan alternatif kepada masyarakat yang menginginkan sistim selain sistim bunga. (Ghufron, 2015)

Undang-Undang No. 7 tahun 1992 tentang Perbankan diamandemen berdasarkan UndangUndang No. 10 Tahun 1998. Dalam amandemen tersebut istilah bank berdasarkan prisip bagi hasil secara yuridis formal telah diubah menjadi bank berdasarkan prinsip syariah. Dalam Pasal 1 angka 13 disebutkan bahwa: "Prinsip Syariah adalah aturan perjanjian berdasarkan hukum Islam antara bank dan pihak lain untuk penyimpanan dana dan atau pembiayaan kegiatan usaha, atau kegiatan lainnya yang dinyatakan sesuai dengan syariah, antara lain pembiayaan berdasarkan prinsip bagi hasil (mudharabah), pembiayaan berdasarkan prinsip penyertaan modal (musyarakah), prinsip jual beli barang dengan memperoleh keuntungan (murabahah), atau pembiayaan barang modal berdasarkan prinsip sewa murni tanpa pilihan (ijarah), atau dengan adanya pilihan pemindahan kepemilikan atas barang yang disewa dari pihak bank oleh pihak lain (ijarah wa iqtinah)".

Dalam perkembangannya Undang-Undang No. 7 tahun 1992 tentang Perbankan sebagaimana diubah berdasarkan Undang-Undang No. 10 Tahun 1998 dirasakan belum mengatur secara sepesifik dan kurang mengakomodasi karakteristik operasional perbankan Islam di Indonesia, sehingga perlu pengaturan yang memadai dan sesuai dengan karakteristiknya. Atas dasar kebutuhan tersebut maka diundangkan Undang-Undang No. 21 Tahun 2008 Tentang Perbankan Syariah. Bank Syariah adalah suatu lembaga keuangan yang menerapkan prinsip atau kaidah ajaran agama Islam, baik mengenai produk-produk maupun dalam menjalankan operasionalnya (Dhaniar, 2020).

Dalam rangka untuk memberikan kepastian hukum bagi stakeholders dan sekaligus memberikan keyakinan kepada masyarakat dalam menggunakan produk dan jasa Bank Syariah, dalam undang-undang ini diatur jenis usaha, ketentuan pelaksanaan syariah, kelayakan usaha, penyaluran dana, dan larangan bagi Bank Syariah. Di samping itu juga diatur tentang kegiatan usaha yang tidak bertentangan dengan prinsip syariah, yaitu meliputi kegiatan usaha yang tidak mengandung unsur-unsur riba, maisir, gharar, haram dan 
zalim. Dalam undang-undang ini juga diatur menge-nai kepatuhan syariah (syariah compliance) yang kewenangannya berada pada Majelis Ulama Indo- nesia (MUI) yang direpresentasikan melalui Dewan Pengawas Syariah (DPS) yang harus dibentuk pada masing-masing Bank Syariah. Diinternal Bank Indonesia juga dibentuk komite per-bankan syariah yang keanggotaannya terdiri atas perwakilan dari Bank Indonesia, Departemen Agama dan unsur masyarakat. Pengaturan yang demikian sesungguhnya adalah dalam rangka agar bank syariah dalam operasionalnya dapat meme- nuhi kepatuhan syariah (syariah compliance) se- hingga dapat tetap menjaga eksistensi dari prinsip- prinsip syariah Islam dalam operasional bank syariah.

Dalam operasional bank syariah, ketentuanketentuan yang telah ditetapkannya dalam undang-undang tidak semuanya dapat dilakukan berdasarkan prinsip syariah. Hal ini disadari bahwa ada model pembiayaan yang kontroversial dikarenakan kendala eksternal dan dalam kasus lain dikarenakan dinamika internal (Ahmed, 2014). Seperti dalam praktik perjanjian mudharabah dan Musyarakah, menurut prinsip syariah dalam perjanjian tersebut sahibul mal tidak boleh meminta jaminan tambahan karena perjanjian tersebut adalah sharing antara sahibul mal dengan mudharib berdasarkan profit and lose sharing, bukan perjanjian utang piutang. Dengan demikian dapat dikatakan bahwa bank syariah dalam operasionalnya telah melakukan penyimpangan terhadap prinsip syariah. Penyimpangan ini dilakukan dengan sosial untuk melindungi pihak penyimpan dana di bank syariah.

Berdasarkan latar belakang tersebut, permasalahan pokok yang akan dibahas dalam penelitian ini adalah tentang kepatuhan Bank Syariah di Indonesia dalam menjalankan kegiatan usahanya terhadap ketentuan syariah compliance. Tujuan utama dari penelitian ini adalah untuk menganalisis kepatuhan Bank Syariah di Indonesia dalam menjalankan kegiatan usahanya terhadap ketentuan syariah compliance sebagaimana ditentukan dalam Undang-undang Nomor: 21 Tahun 2010 tentang Perbankan Syariah, sehingga dapat diketahui ada atau tidak ada penyimpangan dari prinsip syariah dan dapat diketahui pula dasar dari penyimpangan yang dilakukan.

\section{Metode Penelitian}

Penelitian ini merupakan penelitian deskriptif yang bersifat eksploratif, yaitu suatu penelitian yang bertujuan untuk menggambarkan keadaan atau status dari fenomena. (Suharsimi Arikunto 1989). Atas dasar itu maka teknik analisa yang dipergunakan adalah content analisys, yaitu analisa berdasarkan isi dari bahan hukum. Hal ini mengingat bahan hukum yang ada bersifat deskriptif.

\section{Pembahasan}

\subsection{Prinsip-prinsip Syariah dalam Undang- undang Perbankan Syariah}

Bank Islam merupakan bank yang menjalankan kegiatan usahanya berdasarkan prinsipprinsip syariah Islam. Berbeda dengan bank konvensional yang menjalankan kegiatan usahanya berdasarkan sistim bunga. Bunga menurut syariah Islam masuk katagori riba yang haram hukumnya. Lewis dan Algaoud telah menjelaskan tentang apa yang disebut dengan Islamic banking; "Islamic banking provides services to its customers free from interest, and the giving and taking interest is prohibited in all transactions. Islam bans Muslim from taking or giving interest, and this prohibitions makes an Islamic banking system differ fundamentally from a conventional banking". (Lewis and Algoud 2001)

Dari penjelasan tersebut di atas dapat diketahui bahwa antara perbankan Islam dan perbankan konvensional terdapat perbedaan yang fundamental, yaitu perbankan konvensional menerapkan sosial bunga, sedangkan perbankan Islam tidak menerapkan sosial bunga melainkan mendasarkan 


\section{Jurnal Cakrawala Hukum, Volume 11 No. 2 Agustus 2020}

ISSN PRINT 2356-4962 ISSN ONLINE 2598-6538

kegiatannya pada prinsip profit and loss sharing. Islam melarang setiap muslim mengambil atau memberikan bunga dalam setiap transasaksi.

Diterapkannya prinsip profit and loss sharing karena bank Islam memiliki landasan filosofi yang berbeda dengan perbankan konvensional. Landasan filosofi bank berdasarkan syariah adalah asas tatanan ekonomi Islam, yaitu asas keseimbangan yang adil dalam artian mewujudkan keadilan sosial yang berkesejahteraan dan kesejahteraan sosial yang berkeadilan (Suma 2002); (Qardhawai 1995). Dengan dasar filosofis yang demikian maka bank berdasarkan syariah Islam menerapkan empat prinsip dalam operasionalnya yaitu; 1) tidak berdasar atas bunga; 2) menjalankan transaksi dengan obyek yang halal; 3) dalam kontrak mengutamakan keridhaan masing-masing pihak; 4) dalam mengelola dana pihak ketiga dilakukan dengan amanah, jujur dan bertanggungjawab. (Khalil, 2002)

Sehubungan dengan penjelasan tersebut di atas, maka dalam Undang-Undang Nomor 21 Tahun 2008 tentang Perbankan Syariah, pengaturan prinsip-prinsip syariah diatur secara rigid agar dalam pelaksanaan kegiatan usaha bank syariah dapat menerapkan prinsip-prinsip syariah secara kaffah dan istiqomah dan tidak melanggar ketentuan undang-undang. Hal ini telah ditegaskan dalam Penjelasan Pasal 3 Undang-Undang No. 21 Tahun 2008 tentang Perbankan Syariah. Selanjutnya dalam penjelasan umum undang-undang tersebut ditegaskan bahwa untuk menjamin kepastian hukum bagi stakeholders dan keyakinan kepada masyarakat dalam menggunakan produk dan jasa bank syariah telah diatur tentang usaha, ketentuan pelaksanaan syariah, kelayakan usaha, penyaluran dana, dan larangan bagi bank syariah, kegiatan usaha yang tidak bertentangan dengan prinsip syariah meliputi kegiatan usaha yang tidak mengandung unsurunsur riba, maisir, gharar, haram, dan zalim. Selain itu juga diatur mengenai syariah compliance. Dengan kata lain, adalah selalu benar untuk dapat dikatakan bahwa salah satu aspek mendasar yang mem- bedakan Perbankan Islam dan konvensional adalah kepatuhan pada prinsip syariah (shari'ah compliance) (Lathif, 2017).

\subsection{Penyimpangan dalam Praktik dan Alasan Penyimpangan}

Dari uraian di atas jelas bahwa ketentuan peraturan yang mengatur bank syariah dalam menjalankan kegiatannya tidak boleh menyimpang dari prinsip syariah. Dalam menjalankan kegiatannya harus berpedoman pada tujuan sosial Islam atau Maqasid Shariah. (Aris at all, 2013). Namun dalam pelaksanaan kegiatan pembiayaan di bank syariah ada produk yang tidak dapat dilaksanakan sebagaimana ketentuan prinsip syariah, seperti dalam pembiayaan Mudharabah dan Musyarakah.

Mudharabah adalah akad kerjasama usaha antara dua pihak, di mana pihak pertama (shahibul mal) menyediakan seluruh modal, sedangkan pihak lainnya (mudharib) menjadi pengelola. Keuntungan usaha secara mudharabah dibagi menurut kesepakatan yang dituangkan dalam kontrak. Apabila mengalami kerugian, maka kerugian ditanggung oleh pemilik modal selama kerugian itu bukan akibat kelalaian pihak pengelola. Apabila kerugian itu sebagai akibat dari kecurangan atau kelalaian pengelola, maka pengelola harus bertanggungjawab atas kerugian tersebut. (Antonio, 2001) Sedangkan Musyarakah adalah akad kerjasama antara dua pihak atau lebih untuk suatu usaha tertentu yang masing-masing pihak memberikan porsi dana dengan ketentuan bahwa keuntungan akan dibagi sesuai dengan kespakatan (sharing modal). Ketika mengalami kerugian maka kerugian akan ditanggung sesuai dengan porsi dana masingmasing.

Dua macam pembiayaan tersebut di atas pada hakekatnya adalah kerjasama yang didasarkan atas kepercayaan sehingga menurut prinsip syariah tidak diperlukan adanya agunan. Dalam akad tersebut masing-masing pihak berkedudukan sebagai mitra sama-sama menanggung risiko sesuai 
porsi masing-masing. Kalau dalam akad tersebut dipersyaratkan adanya agunan maka ini bukan lagi merupakan akad yang didasarkan pada kerjasama dan kepercayaan, melainkan akad utang-piutang yang masing-masing pihak kedudukannya tidak sama dan tidak seimbang, yaitu antara kreditur dan debitur.

Dalam praktik pemberian pembiayaan di bank syariah ditentukan sebagaimana diatur dalam Pasal 23 dan penjelasannya Undang-Undang Nomor 21 Tahun 2008 Tentang Perbankan Syariah yang menyebutkan bahwa salah satu syarat kelayakan penyaluran dana di bank Syariah adalah adanya agunan. Agunan tersebut dimaksud untuk menanggung pembayaran kembali pembiayaan dari bank Syariah ketika nasabah penerima fasilitas pembiayaan tidak dapat melunasi kewajibannya. Dipersyaratkannya agunan dalam pemberian pembiayaan oleh bank syariah karena pembiayaan itu mengandung risiko kegagalan atau kemacetan dalam pelunasannya yang dapat berpengaruh terhadap kesehatan bank. Dengan demikian bank Syariah dalam pemberian pembiayaan mudharabah dan Musyarakah telah menyimpang dari ketentuan sosial Islam, dengan kata lain telah melanggar prinsip syariah. Oleh karenanya dalam kedudukan yang sama tersebut, menurut sebagian besar ahli ocia Islam menentukan tidak diperbolehkan pemilik modal meminta agunan kepada pelaku usaha. Sebab pemilik usaha yang mensyaratkan adanya agunan berarti telah menempatkan pelaku usaha tidak sama dan sederajat dengan pemilik modal. (Saeed, 1996)

Akad mudharabah dan Musyarakah sulit diterapkan dalam praktik pemberian pembiayaan di perbankan. Dalam hal ini bank syariah akan menghadapi berbagai kesulitan, diantaranya adalah: a). Kejujuran dari pelaku usaha, yaitu menyangkut pembukuan pelaku kegiatan usaha sering tidak sesuai atau melakukan manipulasi pembukuan sehingga tidak sesuai dengan fakta yang ada; b). Kejujuran dalam penggunaan dana yang telah diterima dari bank, berdasarkan akad dana diper- untukkan untuk kegiatan yang sifatnya produktif sesuai dengan proposal yang diajukan, namun seringkali dipergunakan untuk kepentingan konsumtif; c). Kesulitan bagi bank syariah dalam menentukan margin keuntungan: Bank dalam operasionalnya harus mendapatkan keuntungan. Dalam menghitung keuntungan bank akan memasukkan beberapa komponen seperti biaya operasional, biaya overhead, inflasi dan biaya-biaya lain yang akan mempengaruhi besarnya margin keuntungan, dan keuntungan bank ini akan dibebankan kepada nasabah. Mengingat tingkat inflasi juga akan mempengaruhi besarnya margin keuntungan, maka dalam menentukan besarnya dipergunakan satu asumsi yang mengacu pada perhitungan analisis suku bunga bank konvensional, sehingga besarnya nisbah bagi hasil itu tidak berbeda dengan suku bunga yang berlaku di bank konvensional. (Gafoor, 1995) d). Pembiayaan dalam jangka panjang akan mengikat modal dalam waktu yang sangat lama dan berdampak pada pengembalian modal akan berlangsung lama. Pengembalian modal dalam waktu yang lama ini akan berhadapan dengan situasi ketidakpastian serta risiko yang sangat tinggi. Hal ini berbeda dengan kredit yang diberikan oleh bank konvensional, meskipun untuk jangka panjang modalnya dapat cepat kembali sesuai dengan angsuran yang berlangsung dari awal, sehingga ketidakpastian dan risiko tidak setinggi dari ketidakpastian dan risiko yang ada dalam pembiayaan mudharabah. Semakin panjang proyek yang dijalankan akan semakin panjang pula jangka waktu untuk merealisasi pengembalian, sehingga bank syariah tidak dapat segera membayar para deposan secepat bank konvensional. (Ibid.)

Beberapa kesulitan dalam menerapkan akad mudharabah secara murni tersebut di atas memberikan gambaran bahwa penerapan akad mudharabah secara murni banyak mengandung risiko, baik yang menyangkut moralitas dari nasabah penerima pembiayaan maupun dari sisi teknis bisnis. 
Pembiayaan mudharabah yang diberikan dalam jumlah besar, risiko yang dihadapi oleh bank akan semakin besar pula. Risiko terjadinya pembiayaan bermasalah makin tinggi, dan biaya operasional menjadi sangat tinggi, karena bank syariah memerlukan kewaspadaan yang lebih tinggi, di mana bank syariah harus meningkatkan pengawasan yang lebih ketat dengan memperkerjakan para ahli teknisi maupun ahli manajemen untuk mengevaluasi proyek usaha yang dibiayai dengan maksud untuk mencermati dan meneliti jalannya proyek yang dibiayai oleh bank syariah. Besarnya risiko dan tingginya biaya operasional menjadikan pembiayaan mudharabah dan musyarakah kurang menarik untuk dilakukan dalam aktivitas bisnis bank.

Dalam teori sosial Islam penyimpangan sosial dimungkinkan hanya dalam keadaan-keadaan tertentu seperti misalnya: penyimpangan sosial dilakukan berdasarkan pertimbangan kemaslahatan masyarakat atau kepentingan umum; Penyimpangan sosial demi untuk keadilan dan kepentingan sosial. (Ali, 2002) Persyaratan keharusan adanya agunan dalam pembiayaan di Bank Syariah sebagaimana dijelaskan di atas, dapat didasarkan pada teori sosial Islam mengenai penyimpangan sosial. Penyimpangan dalam ketentuan tersebut di atas adalah dalam rangka melaksanakan prinsip kehati-hatian dan dalam rangka kepentingan yang lebih besar yaitu melindungi nasabah penyimpan dana di Bank Syariah, karena dalam penyaluran dana berdasarkan Prinsip Syariah oleh Bank Syariah mengandung risiko kegagalan atau kemacetan dalam pelunasannya sehingga dapat berpengaruh terhadap kesehatan Bank Syariah. Mengingat bahwa penyaluran dana dimaksud bersumber dari dana masyarakat yang disimpan pada Bank Syariah. Risiko yang dihadapi Bank Syariah dapat berpengaruh pula terhadap keamanan dana masyarakat tersebut. Oleh karena itu penyimpangan dalam persyaratan agunan dapat dipahami dalam rangka untuk kepentingan perlindungan dana nasabah dan pelaksanaan prinsip kehati-hatian.
Menurut hukum Islam, persyaratan agunan dalam pembiayaan bertentangan dengan prinsip mudharabah dan Musyarakah itu sendiri, namun karena agunan disini sangat diperlukan dalam rangka kepentingan yang lebih besar, Dalam hukum Islam ini merupakan penyimpangan hukum, namun penyimpangan di sini dalam rangka untuk mewujudkan maslahat (kebaikan) dan menghindarkan mafsadah (kerusakan). Hukum Islam tidak melarang melakukan penyimpangan hukum dalam rangka untuk mewujudkan maslahat dan menghindarkan mafsadah. Teori ini disebut dengan istilah Istihsan, yang mempunyai kemiripan dengan doktrin utility dalam hukum yang pertama kali dikemukakan oleh Jeremy Bentham (Shomad, 2010). Istihsan adalah cara menemukan hukum dengan jalan menyimpang dari ketentuan yang sudah ada demi keadilan dan kemaslahatan sosial atau kepentingan umum. Sesuatu yang baik menurut rasio akan selaras dengan tujuan syariat dalam penetapan hukum.

Agunan di satu sisi bertentangan dengan prinsip syariah dalam pembiayaan mudharabah, namun di sisi yang lain dalam praktik bank syariah agunan mempunyai manfaat yang besar bagi masyarakat umum, yaitu untuk melindungi dana nasabah yang dipercayakan kepada bank syariah. Oleh karena itu menetapkan hukum berdasarkan Istihsan merupakan pembenaran dipersyaratkannya agunan dalam pembiayaan di Bank Syariah.

Dengan demikian dipersyaratkannya agunan dalam Pembiayaan di bank Syariah bukanlah sesuatu yang bertentangan dengan prinsip syariah, melainkan dibenarkan, karena tujuannya adalah dalam rangka mewujudkan keadilan dan kemaslahatan sosial yaitu melindungi kepentingan nasabah penyimpan dana.

\section{Kesimpulan}

Persyaratan agunan dalam pembiayaan Mudharabah dan Musyarakah bertentangan dengan Hukum Islam. Namun dalam praktik Bank 
Syariah di Indonesia persyaratan ini tidak dapat dihindari karena pembiayaan itu sendiri dari aspek teknis maupun ekonomi mengandung risiko yang tinggi. Pembiayaan Mudharabah dan Musyarakah tidak dapat diterapkan secara murni sebagaimana dalam ketentuan hukum Islam. Berdasarkan kenyataan ini maka Bank Syariah di Indonesia melakukan penyimpangan hukum Islam dengan menggunakan metode Istihsan. Penyimpangan ini dibenarkan dengan tujuan untuk keadilan dan kepentingan sosial atau kemaslahatan. Oleh karena itu Bank Syariah mensyaratkan adanya agunan dalam pembiayaan Mudharabah dan Musyarakah tidak melanggar ketentuan syariah compliance sebagaimana diatur dalam Undang-Undang No. 21 Tahun 2008 Tentang Perbankan Syariah.

\section{Daftar pustaka}

Ahmed, H. (2014). Islamic Banking and Shari'ah Compliance: A Product Development Perspective. Journal of Islamic Finance, 3(2), 15 - 29. Retrieved from https://journals.iium.edu.my/iiibf-journal/ index.php/jif/article/view/45

Ali, Muhammad Daud. 2002. Hukum Islam, Pengantar Ilmu Hukum dan Tata Hukum Islam Di Indonesia. Jakarta. Raja Grafindo.

Antonio, Muhammad Syafi'I. 2001. Bank Syariah Dari Teori ke Praktk. Jakarta. Gema Insani Press.

Arikunto, Suharsimi. 1989. Prosedur Penelitian, Suatu Penekatan Praktik. Jakarta. Bina Aksara.

Aris, N. A., Othman, R., Azli, R. M., Sahri, M., Razak, D. A., \& Rahman, Z. A. (2013). Islamic Banking Products: Regulations, Issues and Challenges. Journal of Applied Business Research (JABR), 29(4), 11451156. https://doi.org/10.19030/jabr.v29i4.7922
AZ, Mohammad Ghufron. 2015. The Regulation of Shariah Principles In The Shariah Banking in Indonesia. Journal of Law, Policy and Globalization. Vol 42. 2015.

Budiastanti, D. (2020). Implikasi yuridis putusan Mahkamah Konstitusi nomor 93/PUU-X/2012 terkait dengan penyelesaian sengketa perbankan syariah. Jurnal Cakrawala Hukum, 11(1), 1-11. doi:10.26905/idjch.v11i1.4120.

Gafoor, A.L.M., Abdul. 1995. Interest Free Comercial Banking. Apptec Publications. Netherlands. Groningen.

Khalil, Jafril. 2002. Prinsip Syariah Dalam Perbankan. Jurnal Hukum Bisnis, Volume 20 Agustus-September 2002. Jakarta. Yayasan Pengembangan Hukum Bisnis.

Lathif, M. (2017). Karakteristik islamic banking dalam hukum perbankan Indonesia. Jurnal Cakrawala Hukum, 8(1), 1-11. doi:10.26905/idjch.v8i1.1725.

Lewis, Mervyn K., \& Algaoud, Latif M., 2001, Islamic Banking, Edward Elgar, Cletenham, UK. Northampton MA, USA.

Pramono, Y. (2017). Tanggung gugat perdata bank terhadap klaim bank garansi yang dikeluarkan. Jurnal Cakrawala Hukum, 8(2), 230-239. doi:10.26905/idjch.v8i2.1672.

Saeed, Abdullah. 1996. Islamic Banking and interest: A Study of Prohibitation of Riba and Its Contemporary Interpretation. New York. E.J. Brill.

Shomad, Abd. 2010. Hukum Islam: Penormaan Prinsip Syariah dalam Hukum Islam. Jakarta. Prenada Media Group.

Suma, Muhammad Amin, 2002, Ekonomi Syariah Sebagai Alternatif Sistem Ekonomi Konvensional, Makalah Disajikan Dalam Seminar Perbankan Syariah, Diselenggarakan Oleh BRRC, Jurnal Hukum Bisnis, Law Office REMY \& DARUS, Bekerjasama Dengan Biro Perbankan Syariah Bank Indonesia, Jakarta 18 Juli 2002. 